\title{
$\mathbf{4}$

\section{A retomada crítica da história indígena em Nuestra voz de tierra, memoria y futuro}

Critical recovery of Indigenous history in Nuestra vOz de tierra, memoria y futuro

CÉSAR GERALDO GUIMARÃES

\section{PPGCOM/UFMG}

Doutor em Literatura Comparada pela Universidade Federal de Minas Gerais (1995), professor Titular da Faculdade de Filosofia e Ciências Humanas (FAFICH) da UFMG e pesquisador do Conselho Nacional de Desenvolvimento Científico e Tecnológico (CNPq). https://orcid.org/0000-00018616-6279

cesargg6@gmail.com

\section{LUÍS FLORES}

\section{PPGCOM/UFMG}

Doutorando no PPGCOM/UFMG.

Pesquisador, professor e curador de cinema.

https://orcid.org/0000-00020261-7130.

luisfdf@gmail.com

\section{RESUMO}

Este artigo busca demonstrar de que modo a escritura fílmica de Nuestra voz de tierra, memoria y futuro (1974-1982), de Marta Rodríguez e Jorge Silva, mobiliza uma atitude estética decolonial. Para isso, o texto analisa os principais procedimentos expressivos utilizados pela dupla de cineastas: a mise en scène partilhada com indígenas e camponeses da região do Cauca, na Colômbia, reunindo depoimentos e fabulações, e as operações da montagem voltadas para a desconstrução dos significantes coloniais.

Palavras-chave: estética decolonial; documentário latino-americano; Marta Rodríguez e Jorge Silva

\section{ABSTRACT}

This article aims to demonstrate how the film structure of Nuestra voz de tierra, memoria y futuro (1974-1982) by Marta Rodríguez and Jorge Silva establishes a decolonial aesthetic attitude. In this sense, the text analyzes the main expressive procedures used by the filmmakers: the mise en scene, which is shared with Indians and peasants from the Cauca region, in Colombia, combining testimonies and fabulations; and the montage operations, used to deconstruct the signifiers of the colonial order.

Keywords: decolonial aesthetics; Latin American documentary; Marta Rodríguez and Jorge Silva 
Para o pensador quilombola Antônio Bispo dos Santos, os povos afro-pindorâmicos (ameríndios e afro-brasileiros) desenvolveram, desde sempre, estratégias de contra-colonização para defender seus territórios e os símbolos, significações e modos de vida neles enraizados (SANTOS, 2015, p. 48). Podemos dizer, portanto, que a decolonização teve início com a colonização, a partir das formas materiais e simbólicas de resistência dos povos colonizados. Robert Stam e Ella Shohat, ao analisarem as formações do discurso colonialista, retomam a afirmação de Cedric J. Robinson de que as raízes do radicalismo negro, como resposta especificamente africana à opressão europeia, emergem no contexto das plantações e das minas no Caribe e nas Américas, quando os povos escravizados, sob a violência da diáspora, fizeram valer seus sistemas ontológicos e cosmológicos, assim como suas estruturas sociais: das formas de cultivo à religião, passando pela manutenção da família (STAM; SHOHAT, 2006, p. 120; ROBINSON, 1983, p. 163). Para evitar o embaraço terminológico que tais afirmações porventura possam suscitar, apresentaremos os termos que nos permitirão demonstrar como se dá a invenção de uma atitude decolonial no filme Nuestra voz de tierra, memoria e futuro (1974-1982), de Marta Rodríguez e Jorge Silva.

Reconhecendo, com Maldonado-Torres, a necessidade de uma arquitetura conceitual básica para entrar nesse debate, retomaremos a distinção que ele estabeleceu entre três termos. Se a colonialidade pode ser entendida como a "lógica global de desumanização" - embutida na modernidade - fundada pela conquista do Novo Mundo, a descolonização refere-se às "insurgências históricas contra os ex-impérios e às lutas pela independência", enquanto a decolonização designa a "luta contra a lógica da colonialidade e seus efeitos materiais, epistêmicos e simbólicos", que se espraia desde a colonização até os dias de hoje, alcançando os domínios da experiência vivida, do saber e do poder (MALDONADO-TORRES, 2018, p. 36).

Para os propósitos deste artigo, privilegiaremos o que Maldonado-Torres chamou de giro decolonial estético, definido como "um distanciamento da colonialidade da visão e do sentido" que envolve os aspectos ligados ao tempo, ao espaço, à subjetividade e à espiritualidade (MALDONADO-TORRES, 2018, p. 48). Arriscamo-nos a dizer que a possibilidade de um olhar decolonial no cinema documentário passa necessariamente pela incidência da história e da cosmologia dos povos filmados nos métodos de criação fílmica, em um processo de mão-dupla no qual o filme elabora e reconfigura as forças que o atravessam. Buscando aproximar essa problemática do universo fílmico que abordaremos, seguimos a pista deixada por Amália Cordova no estudo do vídeo indígena na América Latina, retirada, por sua vez, da formulação de Faye Ginsburg em torno das embedded aesthetics: estéticas incrustadas ou enraizadas, como prefere traduzir Cordova (2015, p. 148).

No caso da representação dos povos indígenas na Colômbia, Pablo Mora assinala que em Planas: testimonio de un etnocidio (1972), ao abordarem os massacres e torturas sofridos pelo povo 
guahibo, Marta Rodríguez e Jorge Silva já estavam muito distantes daquela estética que um dia buscou "dar voz" aos que - pretensamente - não a possuíam (MORA, 2015, p. 32-33). Outro passo decisivo se deu quando o Conselho Regional Indígena do Cauca (CRIC) convidou os dois cineastas para realizarem um filme sobre a violência sofrida pelos indígenas sob o regime do presidente Julio César Turbay, com o intuito de oferecer um testemunho sobre a violação dos direitos humanos junto ao Tribunal Russel, na Holanda. Foi assim que surgiu La voz de los sobrevivientes (1980), dedicado à memoria do líder indígena nasa Benjamín Dindicué, assasinado em 1979.

Em Nuestra voz de tierra, memoria y futuro fica ainda mais estreita a colaboração dos autores com os sujeitos filmados, que eram consultados sobre a estrutura narrativa e a montagem, como nos conta a cineasta: "[Eles] vinham assistir à moviola durante seis, sete, oito horas. E, como consideramos que o filme deve servir como uma forma de conhecimento útil, também voltamos a Cauca para projetá-Io"[1] (HOYOS apud MORA, 2012, p. 28). Em seu método de criação compartilhado, o filme não apenas se torna permeável aos mundos dos povos que nele atuam como protagonistas: ele elabora cinematograficamente esse atravessamento. Para retomar os termos de Cordova, queremos mostrar como a estética enraizada desta obra sustenta uma crítica decolonial da imagem. A nosso ver, se é possível reivindicar - como o faz Mignolo (2010) - uma aisthesis decolonial, ela deve se firmar em elementos e processos sensíveis que, de maneira imanente, alcancem por dentro a lógica da colonialidade, desconstruindo-a. Este é, precisamente, o caso de Nuestra voz de tierra, memoria y futuro, que se guia tanto pela negociação e partilha com os sujeitos filmados (indígenas e camponeses da região no Cauca), quanto pelas operações de mise-en-scène e montagem que se valem da história dos personagens (recontada por eles mesmos), bem como de sua cosmologia. Para traduzir o giro decolonial realizado pelo filme sob a forma de operações sensíveis da escritura fílmica, elencamos três grandes procedimentos que o constituem: 1) a desmontagem dos significantes da colonialidade; 2) a encenação dramatúrgica; 3) os testemunhos da luta indígena e camponesa.

\section{DESMONTAR OS SIGNIFICANTES DA COLONIALIDADE}

Seguindo os movimentos dos cinemas novos ao redor do mundo, a década de 1960 trouxe diversas mudanças políticas e sociais para o contexto colombiano. A arte cinematográfica, até então restrita sobretudo à importação de objetos culturais dos Estados Unidos e da Europa, submetida às convenções comerciais da ficção hollywoodiana, passa a adotar um comprometimento 
incisivo com elementos sociais e culturais específicos da Colômbia. Esta afirmação de um olhar independente na tessitura imaginária de um país encontra no gesto documentário uma de suas principais expressões. Uma postura decolonial, que busca contestar o consumo de produtos do colonizador, do imperialista e do capitalista, bem como as representações de mundo sob a égide deles, que reproduzem arranjos de violência e dominação. Marta Rodríguez e Jorge Silva foi possivelmente a dupla de cineastas mais emblemática desse período de renovação insurgente do cinema colombiano. A partir de procedimentos de construção fílmica ao mesmo tempo engajados e inventivos, eles demarcaram uma nova zona de ativação histórica, política e social da Colômbia no século XX. A criação documental, conjugada com dinâmicas concretas da luta indígena e camponesa, resulta em uma atitude francamente decolonial, como ressalta Pedro Pablo Gómez em entrevista com a cineasta (GÓMEZ, 2017, pp. 119-135).

Nuestra voz de tierra, memoria y futuro começa com seis planos fixos que enfatizam - sob diferentes aspectos e escalas - detalhes da estátua do colonizador espanhol Gonzalo Jiménez de Quesada, fundador da cidade de Bogotá, em 1538 (FIG. 1). Realizada pelo escultor Juan de Ávalos e presenteada à cidade pelo governo espanhol, a escultura é como que atacada pela montagem, que busca despojá-la de sua significação heroica e da história dos dominantes que ela monumentaliza. O primeiro plano destaca a mão na espada sob a luz ofuscante, enquanto uma voz feminina diz: "Castrar o sol, foi isto que os estrangeiros vieram fazer aqui"[2]. Trata-se da citação do profeta e cantor maia Chilam Balam, da região de Chumayel, em Yucatán, que descreve, em tons apolípticos, a traumática chegada dos novos deuses trazidos - e impostos pelos conquistadores, em 1541 (2008, p. 28). 

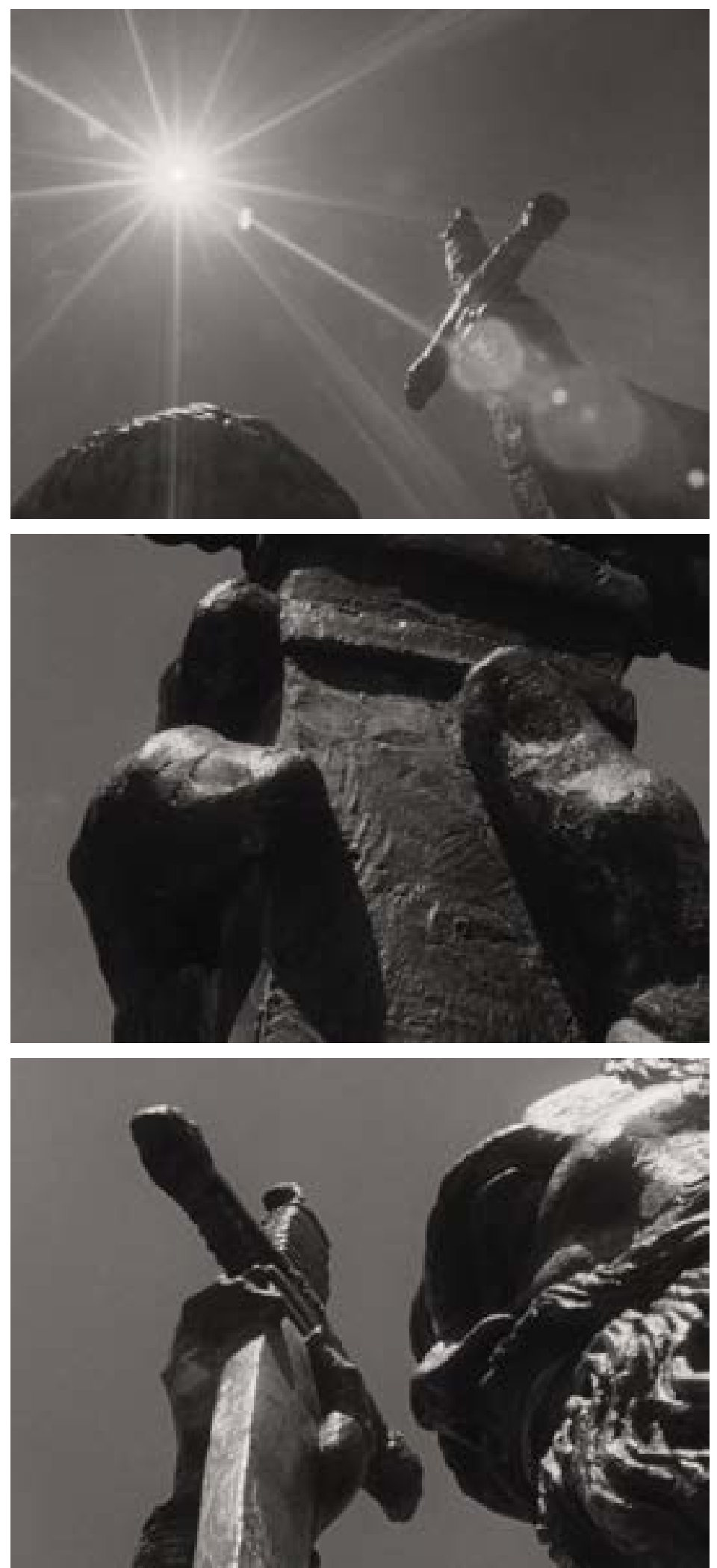

FIGURAS 1A, 1B E 1C: Estátua do colonizador espanhol Gonzalo Jiménez de Quesada Fonte: Nuestra voz de tierra, memoria y futuro. 
O primeiro plano e o close-up destacam a mão e os dedos, tenazmente aferrados ao punho da espada. Sobre esses planos iniciais, avança o ruído do vento que assola a paisagem montanhosa e nevada na qual surge um homem mascarado, de terno e maleta na mão. Esse personagem, que funde as figuras do diabo, do latifundiário branco e do militar, foi inicialmente apresentado à dupla por Julian Avirama (filho do líder coconuco Marcos Avirama), por meio de uma história que eles passaram a chamar de "Mito de la Huecada", provavelmente em referência ao barranco ou "huecada" onde ela se passa ${ }^{[3]}$. Julian contou sobre dois homens que, em busca de algumas vacas extraviadas, sobem às proximidades de um vulcão, local ermo, onde nunca havia nada, e encontram ali, no barranco, um curral de gado vigiado por um capataz que seria o diabo. Depois, acrescentou que o diabo aparece também sob a forma de um policial e de um latifundiário, os três montados a cavalo e com esporas, à maneira dos "conquistadores" da América. Decididos a investigar melhor a narrativa, confrontando-a com outros relatos, Rodriguez e Silva gravaram e transcreveram depoimentos dos habitantes da região, realizando posteriormente um trabalho de leitura e sistematização dos elementos colhidos (RODRIGUEZ; SILVA, 1982b). À maneira de uma improvisação musical, a sequência anuncia alguns dos elementos estruturantes do filme: o olho de uma vaca (alusão ao "Mito de la Huecada"); a figura diabólica; os tanques militares (referência ao autoritarismo reinante); e os protagonistas indígenas (uma mulher que porta um facão; um grupo que levanta suas enxadas e instrumentos de trabalho para o alto, em uma marcha que reconheceremos mais adiante).

O surgimento do título é antecedido pelo plano de uma cavidade na rocha, foco de um movimento de zoom, como se a câmera adentrasse a camada mais arcaica da terra - cabendo lembrar, nesse sentido, que uma significação possível para a palavra "huecada" são as cavidades da terra ou os orifícios do corpo. Não por ocaso, o plano seguinte traz uma múmia com as mãos amarradas (um prisioneiro ancestral capturado pelos conquistadores espanhóis? Um líder indígena ou camponês assassinado pelos latifundiários? Ou uma "peça" de museu?). A câmara ressalta a cavidade vazia do nariz e dos olhos, como que numa rima visual com sua entrada anterior na cavidade da terra. Nesse momento, faz-se a passagem para a desconstrução simbólica da estátua equestre do colonizador Sebastián Belalcázar, em Popayán, capital do departamento de Cauca, fundador da cidade e também de Cali. Criada pelo artista espanhol Victorio Macho, situada no morro de Tulcán (sítio arqueológico da era pré-colombiana), a estátua foi inaugurada para comemorar os 400 anos de Popayán. A voz feminina - com entonação e marcação rítmica conduzidas pela recitação - retorna com o ponto de vista dos primeiros a verem a chegada dos conquistadores, enquanto o zoom "busca" a figura do cavaleiro até fechar seu ângulo na espora (um dos elementos que definem a figura do diabo-latifundiário): 
Homens barbudos e hostis chegam do além mar em grandes barcos de ferro. Carregam em suas mãos fundas de ferro extraordinárias, cujo poder oculto, em vez de atirar pedras, cospe fogo flamejante. E, nos seus pés, têm estranhas estrelas de ferro.

Logo em seguida reaparece a estátua de Gonzalo Gimenez de Quesada, o fundador de Bogotá; em um lento movimento vertical e ascendente, a câmera percorre o rosto do colonizador até alcançar sua mão na espada, enquanto a mesma voz feminina recita: "Quando começaram a desembarcar na América, os conquistadores espanhóis desembarcaram em grande número, montados a cavalo. Em uma mão a cruz, e na outra, a espada". Um corte nos faz mudar de registro e de período temporal. As batidas de tambor, em um desfile que reúne autoridades religiosas, militares e civis, são acompanhadas agora por uma voz over masculina:

\footnotetext{
Assim foi a conquista, para nos expulsar de nossas terras e roubar nossas riquezas. Por isso sabemos que foram primeiramente os espanhóis que começaram a fazer latifúndios, despojando o índio. E que depois seus filhos, e os filhos de seus filhos, seguiram tornando-se grandes proprietários de terras por meio da violência ou aproveitando-se do fato de que nossos pais não sabiam ler nem escrever.
}

Finda a sequência do desfile (com elementos típicos de tantas ditaturas na América Latina, incluindo uma imagem da Virgem carregada em um andor), somos introduzidos ao mundo dos indígenas por uma voz feminina que denuncia a exploração feita pelos brancos latifundiários, enquanto novas imagens continuam a surgir: um rosto de mulher (talvez a que está falando), uma criança com algumas folhas na mão, outra que olha frontalmente para a câmera, um grupo de pessoas à noite, reunidas na cozinha comunitária na fazenda Canaan, retomada pelos indígenas.

\section{ENCENAÇÕES DIABÓLICAS}

Nomearemos "encenações diabólicas" ao procedimento que condensa, na representação dialética do mito e da história, a visualidade da confrontação decolonial. Por um lado, ocorre uma ruptura acentuada com certos pressupostos estéticos do cinema documentário e com a autoridade antropológica/etnográfica no cinema, recusando consensos instituídos historicamente; por outro, percebe-se uma dose elevada de penetração dos aspectos simbólicos e mitológicos que emanam dos sujeitos filmados, individual e coletivamente, trazendo, direta ou indiretamente, para as instâncias de construção imagética, visões de mundo que do contrário permaneceriam enevoadas na superfície da realidade representada. Essas encenações diabólicas criam uma atmosfera mágica de elaboração narrativa e figurativa que vem banhar todo o filme, alcançando 
até mesmo os registros propriamente documentais, como a filmagem de acontecimentos, a desconstrução dos significantes coloniais e os depoimentos dos sujeitos.

Logo após a pompa do desfile religioso e militar, a figura do ginete diabólico, que na abertura cruzava as montanhas nevadas, é convocada novamente em uma sequência na qual o registro documental dos personagens e dos espaços é misturado a uma elaboração narrativa de caráter fabulatório. De partida, o cenário é apresentado com certo mistério, em um plano que sonda a paisagem para enfocar a fazenda Canaan (como informa a legenda na tela). Situada em uma encosta, ela está ligeiramente coberta por brumas, elemento que funciona como um véu e que reforça, desde já, a dimensão encantatória daquilo que vemos, a presença oculta de algo sobrenatural "que representa o poder e suas ameaças, e que manifesta alianças entre a riqueza, o diabo e a Igreja com o âmbito dos fantasmas e a superstição que violenta os crédulos" (VALDERRAMA, 2015, p. 104). Os planos seguintes preservam certa aura fantasmática, não trazendo nenhuma fisionomia humana e centrando-se no corpo de um cavalo cercado por espectros de névoa, com o acompanhamento de uma trilha sonora misteriosa. Não há "quebra de registro" na passagem entre a abertura, que "desmonta" criticamente a estátua equestre do colonizador espanhol Gonzalo Jiménez de Quesada e expõe os motivos da obra, e a encenação algo fabulosa do episódio mítico. Não há fronteira explícita, do ponto de vista formal, separando documentário e ficção, realidade e mito. Tais esferas se misturam de modo indissociável e proporcionam uma multiplicidade de perspectivas, uma construção colaborativa entre quem filma e quem é filmado, entre o que se vê e o que permanece velado. Como afirma Jorge Silva, entrevistado ao lado de Marta Rodriguez pela revista Arcadia va al cine, "a magia está ao lado da realidade e coexiste com ela de uma maneira muito fraternal" (RODRIGUEZ; SILVA, 1982a).

De volta à cozinha comunitária, tem início o relato do "Mito de la Huecada", no qual a busca das reses desgarradas leva os indígenas, montados a cavalo, até o ginete diabólico. Desta vez, escutamos em voz over a história, tal como foi contada aos cineastas por Julián Avirama. A narrativa mítica é encenada com a participação de atores profissionais e dos indígenas coconuco do Cauca. A encenação incorpora, na estruturação da obra, as palavras e as ideias, o pensamento e o imaginário dos sujeitos filmados, que assumem o protagonismo da narrativa. 

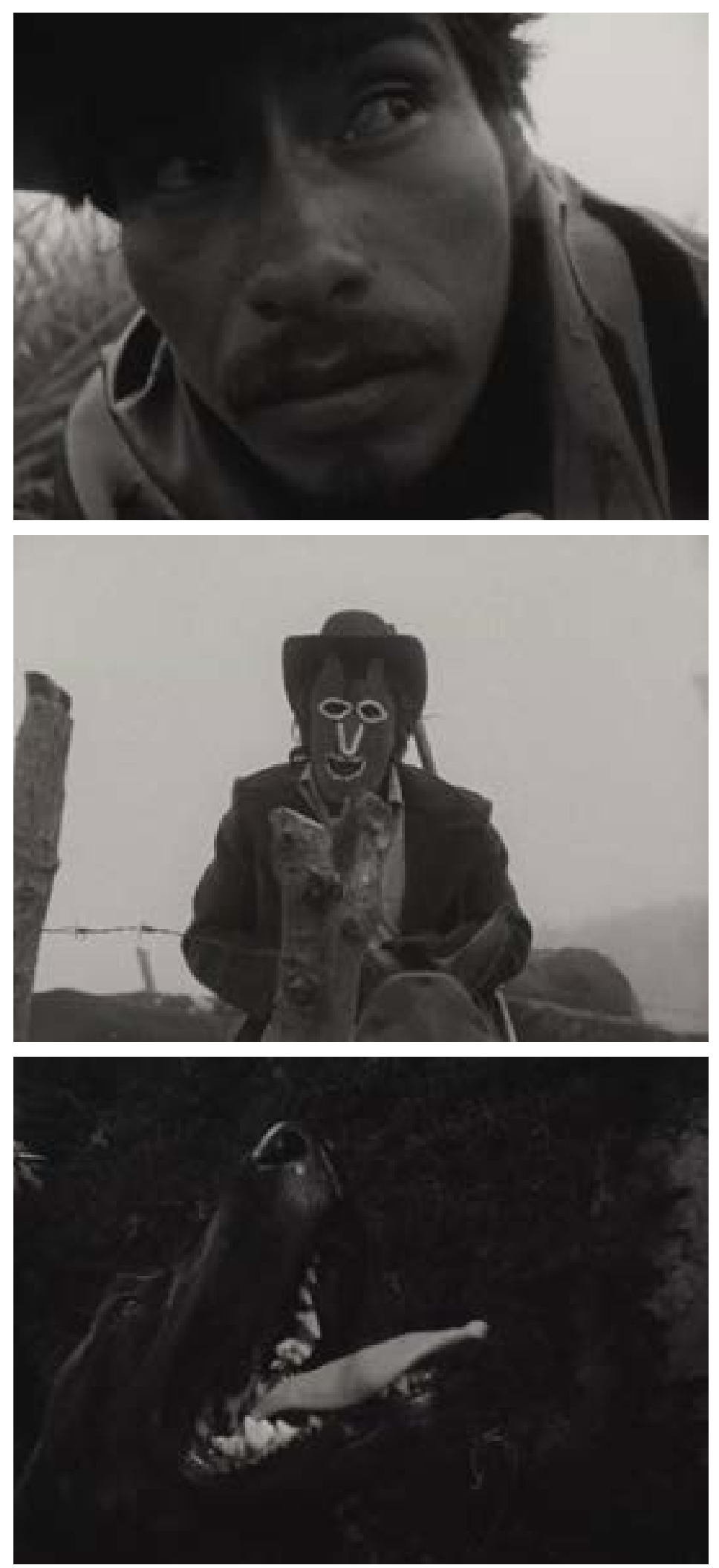

FIGURAS 2A, 2B E 2C: Encenação do "Mito de la Huecada" Fonte: Nuestra voz de tierra, memoria y futuro. 
A montagem introduz, no decurso das encenações, velozes inserções de planos das estátuas dos colonizadores mostradas na abertura, dando a entender que o mito (re)elabora as mutações da história e convoca, em torno dela, conexões simbólicas de outra ordem, que ressignificam a narrativa do poder dominante. $O$ jeito de filmar é bastante desprendido. Por vezes, a câmera assume um ponto de vista distanciado, mostrando os cavaleiros camponeses que percorrem a paisagem montanhosa. O espaço é percorrido por movimentos de zoom, associados às miradas dos personagens em busca da manada. Em duas ou três ocasiões, a câmera se desprende de um centro regulatório do olhar, mostrando o chão, a trilha, as pegadas, flutuando pelo espaço e percorrendo o terreno como se o sondasse. Há, ainda, planos que enquadram mais de perto elementos variados, como os rostos dos camponeses (FIG. 2A), um cão negro com a língua para fora (FIG. 2B) ou o ginete diabólico (FIG. 2C). Quando os indígenas chegam à parte mais alta da região, avistam de longe o curral cercado por pedras, com um grande cão-lobo na entrada, exatamente "às doze horas do dia". Ali, aprisionado entre as rochas, vemos um lote de gado vigiado pelo "encarregado", o mítico ginete diabólico, mostrado primeiro pelas espaldas. A câmera desce do céu todo branco para enquadrar o personagem montado em um cavalo, de costas para nós, imóvel em meio aos bois. Sua presença é decomposta, nos dois planos seguintes, à maneira das estátuas coloniais: primeiro, um close-up da mão direita segurando a rédea, depois um close-up da boca do cavalo domada pela embocadura. Numa dinâmica entre dialética e agonística - irredutível à lógica costumeira do plano/contraplano -, a montagem cria uma contraposição entre os indígenas que espreitam, escondidos no mato, e as figuras do cão infernal e do cavaleiro fantasma.

Em dado momento, a câmera na mão aproxima-se do indígena que, atento, espreita o diabo do lado avesso da paisagem. A câmera se vira bruscamente e mostra seu companheiro, quase irreconhecível, detrás da vegetação. Corta-se para um close-up no rosto do primeiro homem. Surge mais um corte, e o ginete, antes visto de costas, surge agora de frente, como se soubesse que é observado. A câmera aproxima-se dele com um zoom bastante preciso, enfatizando com um close-up sua máscara animal (entre lobo e cão). Um novo corte mostra o olhar - entre ousado e assustado - do primeiro homem. O contra-plano que se segue mostra novamente a figura do diabo, mas agora - espantosamente! - seu rosto, modificado, traz outra máscara, diferente daquela com a qual surgira na abertura do filme. Essa aparição é brevíssima, pois um efeito veloz de movimento rotatório traz de volta o ginete com a máscara de animal. Cortase para o céu, retorna-se para o rosto do primeiro diabo. A figuras continuam se alternando, como espectros fundidos de uma mesma projeção imaginária. Por vezes, a câmera percorre rapidamente a vegetação rasteira, trazendo texturas e abstrações no caminho que conecta dois planos. Os rostos dos indígenas continuam a ser inseridos do outro lado da paisagem, como que confrontando as aparições fantasmagóricas no curral. 

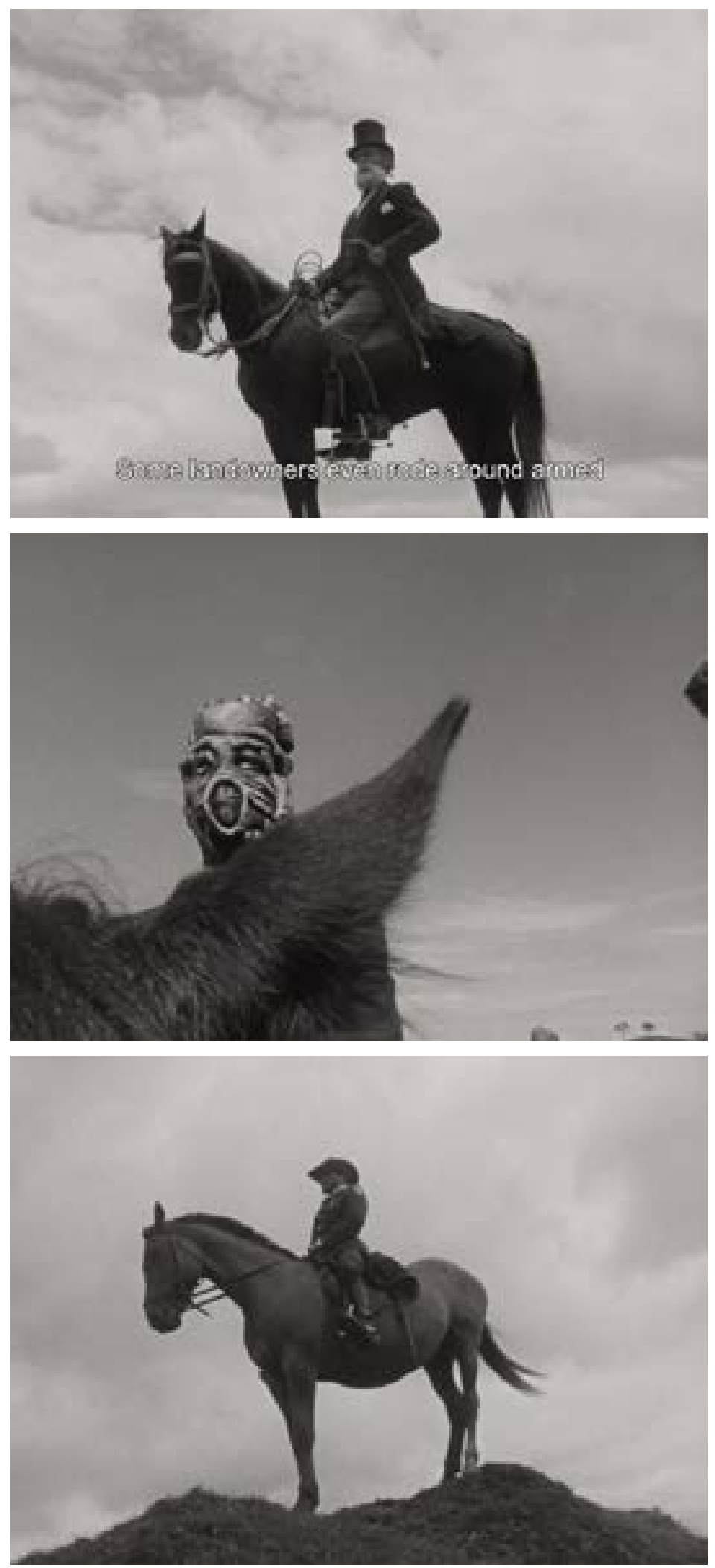

FIGURAS 3A, 3B E 3C: Manifestações do ginete diabólico, conforme o "Mito de la Huecada" Fonte: Nuestra voz de tierra, memoria y futuro. 
Crucial é perceber que não existe uma estrutura inequívoca que oriente as associações destas imagens, dado que elas mudam a todo instante, congregam procedimentos fílmicos variados e expressam, em uma camada subterrânea, a imbricação complexa dos elementos que compõem a realidade. Não se trata de oferecer uma concepção esquemática que simplesmente estabeleça sentidos para aquilo que vemos, seja a partir da adesão ao mito, seja a partir do ponto de vista crítico, distanciado. O mito e a história encontram aqui uma combinação dialética, explosiva, metamórfica, na qual, por um lado, os elementos míticos são submetidos a uma desconstrução e recombinação; e, por outro lado, a história é reaberta para acolher aspectos excluídos das narrativas instituídas e reconfigurar as formas de elaboração do presente a partir de uma releitura do passado.

Os elementos presentes na sequência - os indígenas, as montanhas e o diabo - vão se transformando e ganhando significados condensados ao ritmo das colisões e dos vínculos da montagem. O ginete diabólico passará por diversas metamorfoses, associado a um senhor de terno escuro e barba branca (semelhante à figura de Abraham Lincoln) e também a um policial (FIG. 3). Finalmente, quase no fim da sequência do "Mito de la huecada", ele é devolvido à figura das estátuas, por meio de uma fusão que combina a bota com esporas do cavaleiro diabólico àquelas nos pés de pedra do militar espanhol Sebastián de Belalcázar, o colonizador que dizimou milhares de indígenas e cuja estátua aparecera na abertura do filme). ${ }^{[4]} \mathrm{A}$ utilização manifesta de recursos variados do cinema, ao mesmo tempo em que assinala o caráter de construção das imagens que vemos (transpondo os limites das convenções documentárias e subvertendo os consensos realistas e naturalistas), recusa qualquer unicidade de ponto de vista.

O diabo e os signos convocados ao seu redor retornam em diversos momentos do filme, trazendo fortemente a lógica da população local para compreender as lutas políticas e as violências a que elas respondem. O boi com chifres ao lado da cruz, por exemplo, retorna em uma nova sequência da fazenda Canaan, pontuando o relato sobre as dificuldades da luta. Descobrimos, mais adiante, logo após uma nova aparição do ginete com esporas ("disfarçado" de latifundiário), que trata-se de uma das duas cruzes abençoadas para se proteger do "vento ruim", para filtrálo das forças do mal, pois, como reza um dito local, "o diabo está no vento". O diabo volta, também, na figura do antigo latifundiário, Pacho Arboleda, filmado à maneira de um fantasma e expressando, visualmente, a crença de que a fazenda é assombrada (mesmo os médicos da região acreditam nisso, ouvimos)

Há muitas outras "aparições", com destaque para a sequência do pacto do latifundiário com o diabo, no alto da colina, que remete ao nó imaginário que traduz as opressões vividas pelos indígenas. O mito como que produz uma dobra na história contada pelos dominantes, que exclui os indígenas. A presença dos elementos cosmológicos altera e subverte a memória 
oficial instituída pelos colonizadores. Aproxima-se o cotidiano e o mito, como naquele plano da caixa de fósforos - objeto derivado da industrialização e do progresso - que traz o desenho e o nome de "El Diablo". Os depoimentos dos indígenas relacionam o poder e a riqueza ao diabo, como no episódio emblemático das minas Puracé, comandada por dois estrangeiros. "O diabo é o dono da mina", diz o relato. "O diabo aparece na forma de estrangeiros, bonitos e com cheiro de sulfúreo, aparecem de repente e somem de novo". Segundo um dos indígenas, a cada ano um mineiro deve ser sacrificado ao diabo: "eles morrem ou são mortos", pois este é o pacto do diabo com o gerente da mina. A violência da exploração foi como que traduzida pelo mito, e mesmo a interdição de filmar dentro da mina - pois os danos sofridos pelos trabalhadores não podem ser expostos - adquire um caráter mágico, provando a existência de um pacto com o diabo.

\section{OS TESTEMUNHOS DA LUTA}

A atenção às vozes, rostos, gestos e acontecimentos ligados à recuperação das terras pela população camponesa e indígena é movida por um impulso de reinvenção das formas fílmicas, trazendo consigo a contestação concreta do real. Dentre os protagonistas desta sublevação indígena, o filme destaca as figuras de Gustavo Mejía, um dos fundadores do CRIC - Conselho Regional Indígena do Cauca, em 1971, Marcos Avirama (liderança do povo coconuco) e Gertrudis Lame, viúva de Justianiano Lame, descendente de outra liderança de grande importância na luta histórica dos indígenas nas primeiras décadas do século XX, Manuel Quintín Lame.

Interessada em definir a dimensão crítica do cinema sob os eixos da iconografia, da argumentação visual e da contestação das determinações técnicas e plásticas convencionais, Nicole Brenez define o panfleto fílmico como uma modalidade peculiar de objeção visual às formas audiovisuais correntes, subordinadas à lógica do espetáculo e ao modo industrial capitalista. $\mathrm{O}$ panfleto fílmico cria, sob condições sócio-históricas específicas, modos argumentativos singulares para lidar com determinadas situações. Ao se voltar para as lutas indígenas e camponesas, Nuestra voz de tierra, memoria y futuro toma a forma de um panfleto fílmico no qual a argumentação cinematográfica - à maneira de um laboratório de experimentação formal - se constrói firmada na contestação política (BRENEZ, 2010, p. 10). Isso ocorre quando, por meio de cartazes escritos à mão trazidos pelos indígenas que participam do movimento organizado, são apresentados os sete pontos do programa político do CRIC. O primeiro ponto ("Recuperar nossas terras") é sucedido pelo depoimento de Marcos Avirama, liderança da comunidade coconuca. Ele denuncia 
que seus antepassados tiveram suas terras roubadas, enquanto os latifundiários usurparam os terrenos mais férteis. Seu depoimento prossegue, sobreposto aos planos dos pés descalços e maltratados de uma mulher e uma criança, mostrados em primeiro e primeiríssimo plano.

Depois da enumeração dos outros seis pontos - mas sem coincidir com as palavras de ordem dos cartazes -, outra voz masculina surge sobreposta ao primeiro plano do rosto de Gustavo Mejía (que tem os olhos fechados) e afirma: "A memória coletiva do índio ainda está viva". A voz over menciona aqueles que precederam a luta atual do CRIC: a Cacique Gaitana ${ }^{[5]}$ (ainda no século XVI), Juan Tama[6] (liderança nasa do século XVII) e os líderes José Gonzalo Sanchéz (da etnia totoró) e Eutiquio Timoté (do povo pijao). Nisso, a câmera fecha seu foco na figura de outra liderança, Manuel Quintín Lame, e re-enquadra bem de perto o seu rosto, separando-o dos guardas que o prenderam (a foto atesta uma de suas centenas de prisões; esta, em 1915 ou 1916). A voz over diz que a luta de hoje ainda se guia pelo programa de Lame, da década de 1930. A imagem é agora comentada pela voz de Mejía, ainda fora de quadro: "Ele lutou por muito tempo, e foi muito perseguido". Surge outra fotografia: seria também Lame, com um dos olhos e o lábio deformados pelas torturas que sofreu? Mejía afirma que, mesmo sendo preso centenas de vezes, isso não amedrontava Lame, pois ele sabia que para mudar era preciso seguir lutando. Aqui se descortina uma diferença decisiva: enquanto Lame atuava segundo os marcos da lei, Mejía defende a organização e luta própria dos indígenas. O fecho de sua fala é o plano de um menino que lê atentamente o livreto do CRIC, intitulado Análise de sua organização e suas lutas. Um a um, a câmera de Jorge Silva singulariza os participantes desse levante, desde a mulher que lê a cartilha com a criança no colo até os múltiplos e diversos rostos dos que participam das marchas e encontros (FIG. 4): mulheres, homens, meninos e meninas. "Como lutar sem recuperar a sua própria história?", pergunta a voz over que encerra esta sequência. 

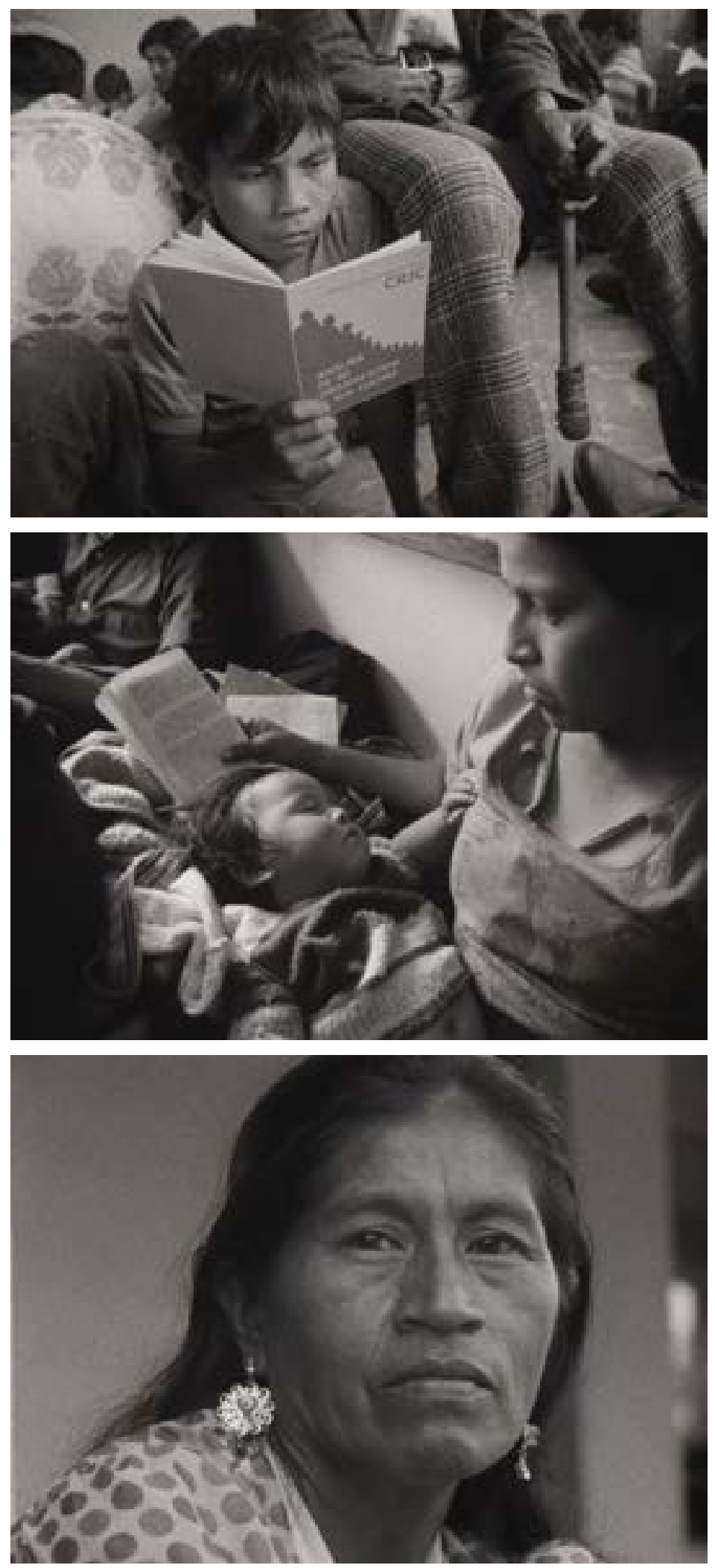

FIGURAS 4A, 4B E 4C: Participantes da luta do CRIC - Conselho Regional Indígena do Cauca.

Fonte: Nuestra voz de tierra, memoria y futuro. 
Outra estratégia de montagem empregada por este panfleto fílmico consiste na combinação de diferentes temporalidades, por ocasião de duas retomadas: uma feita pelos indígenas da comunidade de Coconuco, na reserva de Cobaló, outra realizada pelos camponeses. Entre as duas, que correm como em paralelo, surgem dois depoimentos de Gertrudis Lame (viúva do líder Justianiano Lame), que narra como se deu o assassinato do marido, em uma retomada em 2 de fevereiro de 1977, a mando de uma fazendeira. Na retomada indígena, a montagem se vale mais da associação poética do que das amarras narrativas convencionais. Em dado momento, por exemplo, surgem duas falas (em quadro) que conclamam à retomada: do líder coconuco Marcos Avirama, cercado pelos seus companheiros, que menciona o documento que Ihes assegura a propriedade da reserva, e a da jovem mulher que, firmemente, diz que a terra é deles, e não do arcebispo, além de recomendar aos seus companheiros que, se interpelados pelos juízes a dizerem os nomes dos seus dirigentes, "digam que são a fome e a necessidade". Logo em seguida surgem os planos da procissão na qual aparecem uma autoridade religiosa (em alusão ao arcebispo que se arvora em dono das terras); a imagem da Virgem e o andor que, reenquadrado, assemelha-se mais a um canhão; uma autoridade civil com uma cruz nas mãos; soldados em marcha; e o rosto do Cristo com coroa de espinhos. Mais à frente, outra autoridade religiosa aparecerá, mas desta vez será interrompida pela veemência do discurso de Gustavo Mejía: "Que excelentíssimo arcebispo, que excelentíssimo senhor-de-não-sei quem [...] excelentíssimos somos nós, que trabalhamos a terra, companheiros!". Logo após, acompanhados pelo som de uma flauta, aparecem os planos que enfatizam, plasticamente e pela repetição, os gestos emblemáticos dos indígenas que, um após outro, avançam e passam debaixo da cerca e se apossam da terra, com seus facões e enxadas. Logo após, o depoimento de Gertrudis Lame, com os filhos ao seu lado, faz a passagem para as lutas dos camponeses.

Na retomada camponesa, a montagem ganha uma vibração rítmica e intensiva: no preparo da ocupação, a repetição ritmada do barulho dos facões que são amolados compõe uma música insurgente, adquirindo também o valor de signo emblemático, tal como aquela das enxadas levantadas vistas no início do filme, e que reaparecem aqui em seu contexto original, na retomada do território coconuco. O som dos machados anuncia a assembleia que decidirá pela recuperação das terras, e logo os camponeses surgem passando por baixo das cercas - tal como os coconuco - ação acentuada pela montagem sonora. As duas retomadas - indígena e camponesa convergem para um conjunto de planos jubilosos, conduzidos pela música, que nos mostram a vitória transmutada na germinação das sementes, na amamentação da criança e na brincadeira descontraída do líder Marcos Avirama com uma moça, ele que antes aparecera fazendo denúncias e organizando a retomada das terras. Reaparece também aquele cavidade na rocha, mas agora seu ôco conota a força que brota do interior da terra, e viceja. Esta sequência, porém, nada tem 
de celebratória. A segunda aparição de Gertrudis Lame relembra o quanto a história indígena é marcada pelos desastres e traumas:

A terra, para nós, é nossa mãe. Porque nós a amamos e a trabalhamos. Os latifundiários, por que eles tem necessidade dela? Para tê-la (...) fazendo-nos trabalhar nela, depois de tê-la roubado de nós. (...) É isso que dizia meu esposo, Justiniano. A terra pertence a quem nela trabalha (...) não aos ladrões que a roubaram, assassinando nossos antepassados, fazendo-nos crer que a terra era deles, e que não tínhamos nada, e matando-nos.

A sequência se conclui com o plano geral de uma imensa área cultivada, buscada pelo zoom, e o plano seguinte nos coloca no interior da plantação, enquanto uma voz over afirma que estamos diante do resultado das lutas, e que a decisão deles é de recuperar todas as terras que reivindicaram junto aos conselhos indígenas. Outra vez, não se trata da celebração de uma vitória. Em seus últimos dez minutos, ao jogar com a aparição das palavras ETHNOCÍDIO/HOMICÍDIO, acompanhadas por um lancinante som metálico e pelo seco estampido de tiros, o filme apresenta alguns dos líderes indígenas assassinados: Avelino Ui (em 1978), Benjamin Dindicué (em 1979) e Gustavo Mejía, cuja morte, em 1974, precipitou a ação dos chamados "pájaros", matadores contratados pelos grandes proprietários de terras (PEÑARANDA, 2012, p. 170). "Este é o inimigo que surge em todo lugar", nos diz uma voz, referindo-se ao diabo-latifundiário. Em um fórum da sociedade civil colombiana dedicado aos direitos humanos, Julián Avirama lê a carta enviada da prisão pelo pai (Marcos Avirama), relatando as torturas a que foi submetido. Caminhando para o fim, o filme traz ainda as imagens de Justiniano Lame, um trecho do discurso de Gustavo Mejía (que apela à unificação da esquerda colombiana, "dividida em mil pedaços") e o depoimento final de Gertrudis Lame. Depois do plano que mostra os pés de milho balançando ao vento, ela reaparece remexendo nas cartilhas do CRIC. Ela lembra novamente as palavras do marido, que dizia não ter criado os filhos nem no medo nem no obscurantismo. Reafirma também que um dia os latifundiários pagarão por todos os crimes que cometeram. No plano final, os olhos ternos e firmes do rapaz parecem observá-la.

Servindo-se tanto do registro dos encontros, das marchas e dos acontecimentos que animaram as lutas indígenas e camponesas, quanto da montagem que combina depoimentos dos protagonistas (em quadro), diferentes vozes over (de valor testemunhal e de matizes variados, reflexivas, incitativas, denunciadoras), assim como de vozes que leem diferentes textos, o cinema de Marta Rodríguez e Jorge Silva filma de dentro a luta e o pensamento dos povos indígenas e camponeses do Cauca, expressos em seus próprios termos, como é caso, por exemplo, da sequência que desconstrói a comemoração da "descoberta da América".

Logo após a fala - bajuladora e subserviente - do membro da Academia Colombiana de História, que, numa cerimônia com a presença de um general e outros militares, afirma 
que as Forças Armadas é que ensinaram a história do país, surge uma voz over masculina, que diz: "Eles não nos ensinam a nossa verdadeira história porque ela é inconveniente". Logo em seguida uma cartela exibe os seguintes dizeres: "Recuperação crítica da nossa história". Segue-se, então, um admirável conjunto de relações construídas pela montagem, formando um pequeno panfleto cinematográfico decolonial-visual. Após o plano de uma mulher indígena com uma criança, vemos um rádio suspenso, pendurado por fios. Um mão entra no quadro e liga o rádio. Ouvimos o locutor: "Hoje é 12 de outubro. Dia da raça. Dia de festa nacional. Dia de uma raça inexistente, posto que índios já não temos mais. E os que restam, são de museu. De toda maneira, a celebração é pretexto para o maior weekend do ano". Irônico demais para ser verdadeiro, o texto vem acompanhado das imagens que o contrariam: na cozinha comunitária da fazenda retomada (Canaan), homens e crianças indígenas se alimentam, ao redor de um caldeirão no fogo. Volta o plano da mulher, como se ela escutasse o rádio. Um close-up destaca um adesivo colado no aparelho, um outro cavaleiro: desta vez, o Fantasma, personagem de quadrinhos criado por Lee Falk, montado em seu cavalo chamado Herói. No plano seguinte, em movimento suave e ascendente, a câmera destaca as mãos amarradas daquela múmia que havíamos visto bem no início do filme. Logo, uma voz masculina surge e nos diz que para eles, indígenas, o 12 de outubro é uma data de luto, não de comemoração. Enquanto ela menciona as atrocidades perpetradas pelos conquistadores espanhóis (matavam mulheres e crianças, destruíam aldeias inteiras, saqueavam os tesouros e incendiavam casas), vemos algumas esculturas de figuras ancestrais (seriam deuses?). Com efeito, estamos em um museu, conforme indica a tabuleta onde se lê "Tierradentro - Siglo VII D.C - Siglo IX DC".

Uma heterogênea composição de vozes contestatórias, indígenas e camponesas, sacode e trinca os pilares simbólicos que sustentaram, durante séculos, a colonização espanhola na Colômbia, e que prossegue no processo de modernização autoritária que alcançou toda a América Latina desde os anos 1960. Em especial, os procedimentos da encenação - no qual atuam atores profissionais e os indígenas - trazem gestos dissonantes e figuras que brotam abertamente da escuta e da afirmação tanto da imaginação política do povo coconuco quanto da sua cosmologia. São esses variados procedimentos cinematográficos de Nuestra voz de tierra, memoria y futuro, articulados em diferentes níveis - nas operações da montagem e na construção da mise en scène - que concedem ao filme uma atitude estética decolonial. 


\section{REFERÊNCIAS}

ANÓNIMO. Los libros de Chilam Balam de Chumayel. Caracas: Fundación Editorial el perro y la rana, 2008.

BRENEZ, Nicole. L'objection visuelle. In: BRENEZ, Nicole (éd.), Le cinéma critique: de l'argentique au numérique, voies et formes de l'objection visuelle; travaux de l'École Doctorale Histoire de l'Art, Paris Sorbonne, $\mathrm{n}^{\mathrm{o}}$ 2, 2010.

CÓRDOVA, Amalia. Estéticas enraizadas. Aproximações ao video indígena na América Latina. Belo Horizonte: Catálogo forumdoc.bh — Mostra “Olhar: um ato de resistência”, 2015, pp. 149-180.

GÓMEZ, Pedro Pablo. Marta Rodríguez, descolonizando la representación documental latinoamericana. Estudios Artísticos: revista de investigación creadora, 2017.

HOYOS, Diogo Léon apud MORA, Angelica Mateus. Lo indígena en el cine y vídeo colombianos: panorama histórico. Cuadernos de cine colombiano n. 17 A. Cine y video indígena: del descubrimiento al autodescubrimiento. Bogotá: Cinemateca Distrital-IDARTES, 2012.

MALDONADO-TORRES, Nelson. Analítica da colonialidade e da decolonialidade: algumas dimensões básicas. In: BERNARDINO-COSTA, Joaze; MALDONADO TORRES, Nelson; GROSFOGUEL, Ramón (Orgs). Decolonialidade e pensamento afro-diaspórico. Belo Horizonte: Autêntica, 2018.

MIGNOLO, Walter D. “Aiesthesis decolonial”. In: CALLE14, v. 4, n. 4, jan-jun, 2020.

MORA, Pablo. La autorrepresentación audiovisual indígena en Colombia. In: MORA, P. (Org). Poéticas de la resistencia: el video indígena en Colombia. Bogotá: Cinemateca Distrital-IDARTES, 2015.

PEÑARANDA, Daniel Ricardo. Las guerras de los años ochenta y la resistência contra los actores armados. In: PEÑARANDA, Daniel Ricardo (Org). Nuestra vida ha sido nuestra lucha. Resistencia y memoria en Cauca indígena. Centro Nacional de Memoria Histórica, 2012.

ROBINSON, Cedric J. Black marxism. The making of the black radical tradition. Chapel Hill: University of North Carolina Press, 1983.

RODRIGUEZ, Marta; SILVA, Jorge. "Cineastas por favor abrid los ojos" (Entrevista). In: Arcadia va al cine, Ano 1, n. 3. Bogotá: Editorial Cometa, setembro-outubro de 1982a, pp. 3-13.

RODRIGUEZ, Marta; SILVA, Jorge. "Reportaje a Jorge Silva e Marta Rodriguez”. In: VARGAS, Claudia Triana (ed.). Cuadernos de cine colombiano n. 7. Bogotá: Cinemateca Distrital, outubro de 1982b.

SANTOS, Antônio Bispo dos. Colonização, quilombos. Modos e significados. Brasília: UnB/INCTI (Instituto Nacional de Ciência e Tecnologia de Inclusão no Ensino Superior e na Pesquisa), 2015. 
STAM, Robert; SHOHAT, Ella. Crítica da imagem eurocêntrica. Multiculturalismo e representação. São Paulo: Cosac Naify, 2006.

VALDERRAMA, Hugo Chaparro. Martha Rodriguez: La historia a través de una cámara. Bogotá: Alcadía Mayor de Bogotá, 2015.

[1] No original: "Aquí venían a ver la moviola durante seis, siete, nueve horas. Y como consideramos que la película tiene que servir como forma de conocimiento útil, también regresamos al Cauca para proyectarla".

[2] No original: "Castrar al sol, eso es lo que han venido a hacer aquí los extranjeros".

[3] A palavra espanhola "huecada", que pode remeter também às cavidades da terra, como as cavernas, ou aos orifícios do corpo, como o buraco do nariz, é usada aqui para designar a manifestação geográfica do barranco que serve de cenário para o mito. É certo que uma investigação mais completa das possibilidades de uso dessa palavra demandaria o acesso a elementos etnográficos e linguísticos que não possuímos. Ao mesmo tempo, considerando a relevância do termo para a compreensão do relato, buscamos ao menos apontar os sentidos que a palavra adquire em alguns de seus contextos mais costumeiros. Cabe apontar, ainda, que uma versão sintetizada do "Mito de la Huecada", conforme o relato de Julian Avirama, foi publicada na terceira edição da revista Arcadia va al cine, acompanhando uma entrevista com Marta Rodriguez e Jorge Silva (RODRIGUEZ; SILVA, 1982a).

[4] Em junho de 2020, a estátua foi alvo de um protesto no qual um movimento de estudantes do Cauca a cobriram com um manto negro, por acreditarem que ela representa "o racismo e o domínio de uns sobre os outros". Fonte: https:// www.rcnradio.com/colombia/sur/con-un-manto-negro-amanecio-la-estatua-de-sebastian-de-belalcazar-en-popayan. Acessado em: 10 de setembro de 2020. Além disso, em 16 de setembro de 2020, uma quarta-feira, a estátua foi derrubada por um grupo de indígenas. Na ocasião, Luis Eduardo Calambas, representante do povo misak, afirmou: "Esses símbolos pisoteiam a memória histórica dos povos indígenas, mas também dos afros. Vocês gostariam que em cima dos seus mortos colocassem uma estátua para o assassino?”. Fonte: https://elpais.com/internacional/2020-09-17/un-grupo-deindigenas-derrumba-la-estatua-de-sebastian-de-belalcazar-en-colombia.html. Acessado em: 20 de setembro de 2020.

[5] Guaitipán foi uma cacique da etnia Yalcón, no território de Timaná. Resistiu intensamente contra a colonização, reunindo milhares de indígenas de comunidades distintas (Timanaes, Yalcones, Pijaos e outras) para combater os atos genocidas do bandido espanhol Pedro de Añasco (que havia queimado vivo o filho de Guaitipán) e seus homens, que atuavam por ordem do invasor Sebastián de Balalcázar. Tendo vivido no século XVI, ela recebeu dos espanhóis o apelido de "La Gaitana". Ao longo de sua vida, ela forjou alianças fundamentais e reuniu uma força tremenda, adotando uma 
postura insubmissa, exercendo uma poderosa arte guerreira, deixando um legado de resistência que até hoje perdura entre os indígenas da Colômbia. Fonte: https://enciclopedia.banrepcultural.org/index.php/La_Gaitana. Acessado em: 10 de setembro de 2020.

[6] Juan Tama de la Estrella foi um líder indígena fundamental da história do povo nasa. Tendo liderado diversas lutas importantes contra os invasores espanhóis, ele conseguiu, em 1635, que a coroa espanhola reconhecesse legalmente os territórios indígenas. 